\title{
Koronavirüs Salgınının Toplumsal Yapı Üzerindeki Etkileri: Erzurum Örneği
}

\author{
Effects of the Coronavirus Epidemic on Social Structure: The Case of Erzurum
}

\author{
Dr. Öğr. Üyesi İlknur BEYAZ ÖZBEY (iD
}

\begin{abstract}
$\ddot{O} \mathbf{z}$
Covid-19, küresel dünyayı tehditkâr kuvvetiyle sarsan bir salgın olarak karşımıza çıkmaktadır. Covid-19 salgını, geçmişte deneyimlenen salgınlarla karşılaştırıldığında, belirli bir mekâna bağlı kalmaksızın, sınırları hızlı bir şekilde aşıp, tüm dünyayı etkisi altına almıştır. Bu özelliği itibariyle geçmişte karşılaşılan risk ve tehlikelerden önemli ölçüde ayrılmaktadır. Bu çalışma, insanların salgın döneminden nasıl etkilendiklerini, sosyo-kültürel ve ekonomik ne gibi değişimlerin yaşandığını araştırmayı amaçlamaktadır. Ayrıca virüsün yayılmasını engellemek için alınan tedbirlerin, insanların gündelik yaşam pratiklerini nasıl etkilediği, tedbirler çerçevesinde ne gibi değişimlerin yaşandığı, söz konusu değişimler çerçevesinde ne gibi eşitsizliklerle karşılaşıldığ 1 , bu anlamda insanların ne tür kaygı, korku ve beklenti içerisinde bulundukları, çalışmanın temel sorunsalını oluşturmaktadır. Bu çalışma Erzurum şehir merkezinde, farklı meslek dallarından 14'ü kadın ve 7'si erkek olmak üzere 21 kişiyle nitel araştırma yöntemi aracılı̆̆ıyla derinlemesine mülakatlar gerçekleştirilmiştir. Alan araştırması sonucunda Erzurum'da yaşayanların, salgın sürecinde alınan tedbirlere uymaya dikkat ettikleri, kültürel olarak samimi ilişkilerin tedbirlere dikkat etmeyi engellediği görülmüştür. Alınan tedbirler kapsamında sosyal izolasyonun, toplumsal ilişkileri olumsuz yönde etkilemesi, kadınların iş yükünü arttırmasına karşılık, aile ilişkilerini kuvvetlendirdiği sonucuna ulaşılmıştır. Söz konusu tedbirlerin, belirli avantajlarının bulunduğu, fakat eğitim, ekonomi ve sağlık gibi alanlarda belirli eşitsizlikleri ortaya çıkardığ anlaşılmıştır. Salgın döneminde insanların yakınlarını kaybetme korkusu; virüsün seyri, sağlık ve ekonomik yönden kendilerini gelecekte nelerin beklediğinin belirsizliği; normal yaşam pratiklerine dönme beklentisi içerisinde oldukları sonucuna ulaşılmıştır.
\end{abstract}

Anahtar Kelimeler: Koronavirüs, salgın, toplumsal yapı, Erzurum

Makale Türü: Araştırma

\begin{abstract}
Covid-19 emerges as an epidemic that shook the global world with its threatening power. Compared to the epidemics experienced in the past, the Covid-19 epidemic quickly crossed borders and affected the whole world, regardless of a specific location. Due to this feature, it differs significantly from the risks and dangers encountered in the past. This study aims to investigate how people are affected by the epidemic period and what socio-cultural and economic changes have been experienced. In addition, how the measures taken to prevent the spread of the virus affect the daily life practices of people, what changes are experienced within the framework of the measures, what inequalities are encountered within the framework of these changes, what kind of anxiety, fear and expectation people have in this sense constitute the main problematic of the study. In this study, in-depth interviews were conducted with 21 people, 14 women and 7 men, from different professions in the city center of Erzurum, using the qualitative research method. As a result of the field research, it was observed that those living in Erzurum paid attention to comply with the measures taken during the epidemic process, and culturally intimate relations prevented attention.
\end{abstract}

Keywords: Coronavirus, epidemic, social structure, Erzurum

\footnotetext{
${ }^{1}$ Artvin Çoruh Üniversitesi, Fen-Edebiyat Fakültesi, Sosyoloji Bölümü. ilknurbeyaz087@gmail.com

Atıf için (to cite): Beyaz Özbey, İ. (2021). Koronavirüs salgınının toplumsal yapı üzerindeki etkileri: Erzurum örneği. Afyon Kocatepe Üniversitesi Sosyal Bilimler Dergisi, 23(3), 821-839.
} 
Paper Type: Research

\section{Giriş}

Firsatlar kadar krizleri de üreten günümüz modern toplumunda riskler ve tehlikeler (insanlar, hayvanlar, bitkiler üzerindeki) tehdidin küresel doğası ve modern sebepleri olması bakımından geçmiştekilerden ayrılmaktadır (Beck, 2011, s. 25). Günümüz dünyasındaki risk ve tehlikeler, sınırları aşması ve yüksek etki oranı ile geçmişteki risk ve tehlikelerden ayrılmaktadır. Geçmişte karşılaşılan riskler ve tehlikeler; depremler, salgın hastalıklar gibi doğal afetler, günümüz dünyasında da varlığını devam ettirmektedir. Geçmişten farklı olarak günümüzde endüstrileşme ve yaşam biçimi sağlık alanında riskleri artırmıştır. Sözü edilen risklerin başında salgın hastalıklar gelmektedir. Salgın hastalıklardan olan ve günümüz dünyasını küresel boyutta tehdit eden virüslerden birisi ise, Covid-19'dur.

Covid-19 ilk olarak Çin'in Vuhan Eyaleti'nde Aralık ayının sonlarında solunum yolu belirtileri (ateş, öksürük, nefes darlığı) gelişen bir grup hastada yapılan araştırmalar sonucunda 13 Ocak 2020'de tanımlanan bir virüstür. Salgın başlangıçta bu bölgedeki deniz ürünleri ve hayvan pazarında bulunanlarda tespit edilmiştir. Daha sonra insandan insana bulaşarak Wuhan başta olmak üzere Hubei eyaletindeki diğer şehirlere ve Çin Halk Cumhuriyeti'nin diğer eyaletlerine ve dünyanın geri kalan kısımlarına yayılmıştır. Bu anlamda dünyayı her açıdan sosyo-ekonomik, politik bir krizin içine sokan ve dört ayda tüm dünyaya yayılan salgın, Mart 2020’de Dünya Sağlık Örgütü tarafından Pandemi ilan edildi (Lika, 2020, s. 9).

Küresel bir salgın hastalık olarak ortaya çıkan Covid-19, milyonlarca insanın yaşamını yitirmesi sebebiyle bütün bir insanlığı tehdit etmeye devam etmektedir. Geçmişteki salgınlarla karşılaştırıldığında Covid-19, sınırları hızlı bir şekilde aşıp, tüm dünyayı etkisi altına almıştır. $\mathrm{Bu}$ özelliği itibariyle covid-19, geçmişin sağlıkla alanındaki tehlikeleri ve risklerinden ayrılmaktadır. Bu durum ise, esasında modernleşmenin üretmiş olduğu risklerin, tehlikelerin ve salgınların, belirli bir mekâna bağlı kalmaksızın etkisi ve hızının devasa büyüklükte olduğunu göstermekte ve bu anlamda dünya ölçeğinde insan yaşamını tehdit etmektedir. Bu anlamda bu çalışma, küresel ölçekte insanları tehdit eden covid-19 salgınını konu edinmektedir. Çalışmanın temel amacı ise, salgının insanları nasıl etkilediğini göstermektir. Virüsün yayılmasını engellemek için alınan tedbirlerin, insanların gündelik yaşam pratiklerini nasıl etkilediği, tedbirler çerçevesinde sağlık alanında ne gibi değişimlerin yaşandığı, söz konusu değişimler çerçevesinde ne gibi eşitsizliklerle karşılaşıldığı, bu anlamda insanların ne tür kaygı, korku ve beklenti içerisinde bulundukları, çalışmanın temel sorunsalını oluşturmaktadır. Bu sorunsal çerçevesinde, bu çalışmada, Erzurum'da farklı mesleklere sahip insanların salgın döneminden nasıl etkilendikleri ve sosyo-kültürel ve ekonomik ne gibi değişimlerin yaşandığ anlaşılmaya çalışılmıştır.

\section{Koronavirüs Salgını ve Toplumsal Yapı Üzerindeki Etkileri}

Salgın hastalıklar, bireyleri ve toplumları doğrudan etkilemektedir. Salgın hastalıkların etkileri zamana, mekâna, bağlama, topluma, kültüre ve sosyal gruplara bağlı olarak değişiklik göstermektedir. Tarihsel süreçte veba, kolera, sıtma, çiçek, tifo, kızamık, frengi gibi hastalıklar birçok insanın hayatını kaybetmesine neden olmuştur. Bu anlamda farklı zamanla dilimlerinde farklı salgın hastalıklarla karşılaşmak mümkündür (Kılıç, 2020). Zika, MERS, SARS, Ebola gibi salgınlar, içinde bulunduğumuz yüzyılda gerçek bir pandemi / salgın tehlikesinin ortaya çıkma ihtimaline karşı hem gelişmiş hem de gelişmekte olan ülkelerde büyük kaygı yaratmıştır (Taştan, 2020, s. 7). Özellikle en son yaşanan Covid-19 adıyla bilinen salgın tüm dünyaya yayılmış ve olumsuz yönde etkiler bırakmıştır.

Covid-19 sonrasıyla ilgili üç temel öngörünün öne çıtı̆̆g söylenebilir: Birincisi, salgının sadece sağlı sistemini değil, yaşamın bütün boyutlarını etkileyeceği öngörüsüdür. 
İkincisi, salgın sonrasında hiçbir şeyin eskisi gibi olmayacağı iddiasıdır. Üçüncüsü ise yeni normallerle yaşamaya devam edileceği değerlendirmesidir. Söz konusu öngörülerin getireceği yeni arayışlarla birlikte birçok hususun sorgulanması ve sorgulamalar sonucunda da birçok şeyin değişime uğrayacağı iddia edilmektedir. Sorgulamalar; ekonomik, kültürel, sosyal, hukuki, siyasal, sağlık ve eğitim sistemleri, dini hayat, aile yapısı, kültürel kimlik meseleleri, uluslararası ilişkiler ve teknolojik/dijital yaşam gibi yaşadığımız dönemin etkili yaşam bileşenleri ve boyutları üzerinde olacaktır. Çünkü salgın, saydığımız bu yaşam boyutlarının hepsi üzerinde az ya da çok etkili olmakta ve olmaya da devam etmektedir (Karakaş, 2020, s. 545-546).

Covid-19 salgınının dünya ölçeğinde milyonlarca insanın hastalığa yakalanmasına ve yaşamını yitirmesine sebep olması, salgınla mücadeleyi gerektirmiştir. Salgın küresel ölçekte ortaya çıkmasına rağmen, salgınla mücadele ulusal düzeyde yapılmaktadır. $\mathrm{Bu}$ anlamda ilk ortaya çıktığı andan itibaren her ülke ulusal anlamda önlem almaya çalışmıştır. Hastalığın kesin çözümü olarak görülen aşı ve ilaç çalışmaları da henüz cevap vermediği için, vaka sayıları her geçen gün artmakta ve hayatta kalmak adına alınan önlemlere yenileri eklenmektedir. Alınan önlemlerin yetersiz kalması ve ulusal ve uluslararası düzeyde yapılan mücadelelerin başarısız sonuçlar ortaya koyması, salgınla mücadele üzerinde olumsuz etkilere neden olmuştur. Özellikle toplumsal, ekonomik, siyasal ve kültürel anlamda ne gibi yan etkilerinin olduğu tartışılmakta ve bu tartışmalar geleceğe dair soru işaretlerini de içerisinde barındırmaktadır. Salgın toplumların örgütlenme biçimlerini, toplumsal ilişki ve etkileşim biçimlerini doğrudan etkilemiştir.

Virüsün ne yönde ilerleyeceği yönündeki belirsizlik, insanların nasıl bir tavır sergilemeleri noktasında muğlaklığın yaşanmasına neden olmaktadır. Virüsün hızlı bir şekilde yayılması ve mahiyeti konusunda bilinmemezlik, insanların sağlığını ciddi boyutlarda tehdit etmekte, bu anlamda gündelik yaşamda öncelikler değişmektedir. Belirsizliğin hakim olduğu koşullarda insanların yapabileceği tek şey sağlık kurallarına uyum sağlayarak kendilerini ve sosyal etkileşimde bulundukları çevrelerini korumak olmaktadır. Covid-19 salgınının oluşturduğu riskler, toplumsal yaşamı doğrudan tehdit etmeye devam etmektedir. Söz konusu salgın, toplumsal hafızamızda büyük bir kırılmaya neden olmuştur. Çünkü salgının yarattığı atmosferde insanlar, bir yandan yaşadıklarını anlamlandırmaya, karşılaştıkları olumsuz durumları bertaraf etmeye çalışırken, diğer taraftan virüsün barındırdığı belirsizlikle mücadele etmektedirler. Koronavirüs nasıl bir seyir izleyecek, neler getirip neler götürecek, salgın sonrasında neler değişecek, sosyo-kültürel, ekonomik, siyasi ilişkiler nasıl şekillenecek? Tüm bu sorular salgının seyrine bağlı olarak belirsizliğini sürdürürken, toplumsal yapı üzerinde önemli değişime neden olmaktadır.

\section{Yöntem}

Çalışmada, koronavirüs salgınının toplumsal grupları, kurumları, ilişkileri ve etkileşim ağlarını içeren toplumsal yapı üzerindeki etkilerini anlayabilmek için, sosyolojinin araştırma yöntemlerinden nitel araştırma yöntemine başvurulmuştur. Nitel araştırma sosyal süreç ve olaylar üzerinden hareket ederek bağlamı içerisindeki anlamları araştırır. Toplumsal hayattaki farklı bakış açıları üzerinden hareket ederek, bireyleri, grupları, toplumları anlamayı amaçlar (Neuman, 2012). Çalışmada, nitel araştırma yöntemi kapsamında derinlemesine mülakat tekniğine başvurulmuştur. Derinlemesine mülakat ya da görüşme tekniği, nitel araştırmada kullanılan veri toplama tekniklerinden biridir. Nitel araştırmada görüşme, temel veri toplama araçlarındandır. İnsanların gerçekliğe ilişkin algılarına, anlamlarına, tanımlamalarına ve gerçeği inşa edişlerine vakıf olmanın iyi bir yoludur. Aynı zamanda, başkalarını anlamak için kullanılan en güçlü yöntemlerdendir (Punch 2011, ss. 165-166). Detaylı bir bakış ve anlamlandırma sunan nitel araştırma yöntemi ve derinlemesine mülakat tekniği, görünenin ardındaki görünmeyeni görünür kılmayı amaçlamaktadır. Toplumsal yaşamı bütün yönleriyle araştırmak için başvurulan söz konusu yöntem ve teknik, çalışmanın sorunsalını detaylı bir araştırma olanağı sunmaktadir. 
Çalışma, Erzurum şehir merkezinde gerçekleştirilmiştir. Çalışmanın evrenini Erzurum'da yaşayan insanlar oluşturmaktadır. Örneklem ise, Erzurum'un yalnızca il merkezinde yaşayanlardan oluşmaktadır. Bu açıdan Erzurum'un ilçe ve köylerinde yaşayanlar örneklemin dışında tutulmuştur. Çalışmada, Erzurum il merkezinde yaşayan 14'ü kadın ve 7'si erkek olmak üzere toplamda 21 kişiyle görüşülmüştür (Bkz. Tablo-1). Görüşmeye katılanların seçiminde farklı mesleklere sahip insanlar rastgele seçilmiş olup, seçim yapılırken dengeli bir dağılımın yapılmasına dikkat edilmiştir. Görüşmeler, görüşülenlerle yüz yüze gerçekleştirilirken; görüşme esnasında, görüşmecilerin de izni alınarak ses kayıt cihazı kullanılmıştır. Görüşmeler, 28 Eylül-18 Ekim 2020 tarihleri arasında gerçekleştirilmiştir. Çalışmaya ait E-18457941-050.01.04-14077 No'lu etik kurul raporu Artvin Çoruh Üniversitesi Rektörlüğü tarafından 31.12.2020 tarihinde alınmıştır. Görüşülenlere ait bilgiler ise şu şekildedir:

Tablo 1.Görüşmecilere ait demografik bilgiler

\begin{tabular}{cccccc}
\hline Görüşmeci & Cinsiyet & Yaş & Eğitim & Meslek & Medeni Durumu \\
\hline G1 & Kadın & 31 & Lisans & Öğretmen & Evli \\
G2 & Erkek & 30 & Lisans & Zabıt Katibi & Bekar \\
G3 & Erkek & 35 & Lisans & Eczacı & Evli \\
G4 & Erkek & 39 & Lisans & Eczacı & Evli \\
G5 & Erkek & 56 & Lise & Büfeci & Evli \\
G6 & Erkek & 33 & Lise & Pastane İşletmecisi & Evli \\
G7 & Erkek & 42 & Yüksek Lisans & Öğretmen & Evli \\
G8 & Kadın & 28 & Lisans & Bankacı & Bekar \\
G9 & Kadın & 43 & Lise & Kuaför & Evli \\
G10 & Kadın & 44 & Lise & Kuaför & Evli \\
G11 & Erkek & 35 & Lisans & Avukat & Evli \\
G12 & Kadın & 32 & Lisans & Gençlik Merkezi Çalışanı & Bekar \\
G13 & Kadın & 31 & Lisans & Öğretmen & Evli \\
G14 & Kadın & 29 & Lise & Sağlık Çalı̧̧anı-Temizlik Personeli & Evli \\
G15 & Kadın & 34 & Yüksek Lisans & Doktor & Bekar \\
G16 & Kadın & 25 & Lisans & Hemşire & Bekar \\
G17 & Kadın & 29 & Lisans & Hemşire & Evli \\
G18 & Kadın & 28 & Lisans & Hemşire & Bekar \\
G19 & Kadın & 35 & Önlisans & Sağlık Çalı̧anı-Tıbbi Sekreter & Evli \\
G20 & Kadın & 37 & Önlisans & Sağlık Çalışanı-Tıbbi Sekreter & Evli \\
G21 & Kadın & 31 & Lisans & Sağlı Çalışanı-Tercüman & Evli \\
\hline
\end{tabular}

\section{Araştırma Bulgularının Değerlendirilmesi}

Alan araştırmasından elde edilen bulgular, çalışmanın temel sorunsalı 1şığında değerlendirilmiştir. Görüşülen kişiler G1, G2 şeklinde kodlanmıştır.

\subsection{Koronavirüs Salgınına Yönelik Algılar, Tutumlar ve Tepkiler}

Koronavirüs salgını toplumun bütün kesimlerini etkisi altına aldığı için, bu salgına yönelik birbirinden farklı algılamaların olduğu görülmektedir. Salgının etkilerini her birey farklı şekilde deneyimlediği için, salgına yönelik tutumlar ve tepkiler de farklılaşmaktadır. Bu anlamda Erzurum'da yaşayanların Covid-19 hakkındaki algıları, tutumları ve tepkileri şu şekildedir:

"İnsanları çok olumsuz yönde etkiledi özellikle psikolojik olarak. Sosyallik azaldı, insanlar birbirlerinden uzaklaştı. Çevremdeki herkese acaba mikrobu taşıyor mu endişesiyle yaklaşmıyorum. İnsanlar bu konuda çok rahat. Hiçbir tedbir almadan dışarıda dolaşıyor ve başkalarının hayatını tehlikeye sokuyor. Adliyede, adamın işi var gelmiş yanımıza, hiç dikkat etmiyor. Maske var ama çenesinin altında. Sosyal mesafeye dikkat etmiyorlar" (G2).

"Covid, bela, musibet başımıza gelen. Musibet, ama insanları temizliğe yöneltti. El yıkamayı öğretti, temiz gezmeyi öğretti” (G5). 
"Benim için ișkence bu virüs. İnsanları çok kötü etkiledi. İnsanlar birbirine yaklaşamıyor artık. Bazıları dikkat ediyor bazıları dikkat etmiyor. İşin garibi çok dikkat eden virüse yakalanıyor.” (G7).

"Laboratuvar ortamında oluşturulan bir virüs. Biyolojik bir savaş. Yaşlı nüfusu nasıl imha ederiz diye düşündüler ve bu virüs ortaya çıktı. Çok da etkili oldular. Çevremdeki insanların bilinçliliği daha fazla. Bu kadarını beklemiyordum. Apartmanın girişinde dezenfektan bulunması, babamın sürekli elini yıkaması, mümkün olsa ekmeği yıkayacak hale geldik. Bir akrabamız bütün paraları yıkıyordu" (G8).

"İnsanlara bakış açın da değişiyor. Adamın temizliğe dikkat etmediğini yorumlayabiliyorsun. Başkasının hakkına riayet edip etmediğini görebiliyorsun. Geçen asansöre biniyorum koşarak bir adam geldi açtı kapıyı ve maskesiz. Dedim ki, ya sen çık ya ben çıkayım? Neden dedi, dedim masken yok niye olacak. Düşünsene sen nefesinden feragat edip maske takıyorsun, adamın umurunda değil" (G11).

"Bu süreç aslında insan olduğumu fark ettirdi. Evde kalma süreci, insanın kendi özüne dönüşünü sağladı. Kendimi durdum ve dinledim. Hayatım işe git, işten gel, arkadaşlarınla bir yerlerde otur, hep bundan ibaretti. Hayatın bunlardan ibaret olmadığını anladım.” (G12).

"Biraz hayatınıza düzene sokun demek istedi bu virüs aslında. Bir oturup düşünün, durun, bir şu evinize girin artık! dedi. Girin bakın ki normalde siz nesiniz. Çok hızlı yaşıyorduk, durun bir soluklanın, yaşadığınız şeyin farkına varın dedi” (G14).

Salgın hastalıklar, insanları ciddi anlamda tehdit etmeye devam etmektedir. Salgını önlemek, salgına yakalanmış insanların hangi düzen içerisinde tedavi ettirileceği ve nerede bakılacağı, alınacak olan tedbirler salgına karşı verilen mücadelede etkili hususlardır. Salgını önlemek için aniden sosyal izolasyonun insanlarda panik, korku, güvensizlik gibi duygulara yol açtığ 1 görülmektedir (Tansü, 2020, s. 8). Covid-19 ilk ortaya çıktığ1 andan itibaren insanlarda korku ve endişe duygusu oluşturmaktadır. Ne olduğu hakkında bilinmezliğin vermiş olduğu hassasiyetle, kendimi ve çevremi nasıl korurum ya da kendimden ve çevremden virüsü nasıl uzak tutarım düşüncesi ağır basmaktadır. Bu durum doğal olarak sağlık kurallarına uymayı, uymayanlara dikkat etmeyi, onları uyarmayı ve eleştirmeyi gündeme getirmektedir. Özellikle sağlık kurallarına uymayanların ya da uymak istemeyenlerin daha çok virüsü önemsemeyenlerden oluştuğu düşünülmektedir. Başka bir ifadeyle, virüsü önemsemeyenlerin doğal olarak kurallara dikkat etmediklerini de vurgulamaktadırlar. Salgının sözü edilen negatif yönlerinin yanı sıra pozitif yönlerinin olduğu da görülmüştür. Bu bağlamda, salgın, insanlara belirli kazanımlar da kazandırmaktadır. Virüsten korunmanın ilk şartı olan hijyen kuralları, insanları temiz olmaya, temiz kalmaya ve temizliğe dikkat etmeye yöneltmiştir. Virüsü kendilerinden uzak tutarken aynı zamanda kendi hayatları hakkında düşünmeye, anlamlandırmaya ve yorumlamaya da sevk etmiştir. Esasında sosyal izolasyon, insanın kendiyle baş başa kalmasına neden olurken, gündelik yaşamları hakkında muhakeme yapmalarını da sağlamıştır.

\subsection{Evde Kal! Uygulaması ve Aile İlișkileri}

Covid-19 salgını ortaya çıktığı andan itibaren birçok insanı olumsuz yönde etkilemiştir. Virüsün ciddiyetinin farkına varılmasıyla birlikte vaka sayılarını azaltmak ve hastalığın önüne geçmek için birçok önlem alınmaya çalışılmıştır. Bireysel ve toplumsal olarak alınan önlemlerin başında hijyen kuralları, sosyal mesafeye dikkat etmek, sokağa çıkma yasakları, seyahat kısıtlaması, insan akışının durdurulması için belirli iş yerlerinin kapatılması gelmektedir (Acar, 
2020). Salgını önlemek amaçlı alınan tedbirler, birey ve toplum üzerinde önemli etkiler oluşturmaktadır. Özellikle alınan tedbirler, gündelik yaşamda insanların alışkanlıklarını değiştirerek aile ilişkilerini etkilemektedir. Söz konusu tedbirlerden birisi "Evde kal!" yani sosyal izolasyondur. Sosyal bir varlık olan insan, bu süreci sosyal olandan uzakta kalarak ve günümüzün iletişim olanaklarından (telefon, sosyal medya, internet vb.) yararlanarak evde geçirmiştir. Dolayısıyla bu sürecin aile ilişkilerine olumlu ve olumsuz yansımaları da görülmektedir. Bu anlamda söz konusu sürecin Erzurum'da yaşayan farklı meslek grubundan seçilen insanlar üzerindeki etkileri şu şekildedir:

"Annemin babamın yanına gidemiyorum. Uzunca bir süre de gidemedim. Bende olursa, ya onlara bulaştırırsam diye. Sonuçta yaşlı insanlar. Bir de hastalığın ilk dönemlerinden beri, hep risklerle iç içeyiz meslek olarak. Çok yakın temastayız insanlarla." (G4).

"Virüs insanları birbirinden ayırdı aslındı. İnsanlar arasındaki samimiyeti bozdu. Cenazeye gitme, hasta görmesine gitme, aralar açıldı doğal olarak. İnsanlar zaten birbirlerine gidip gelmeyi sevmiyordu, şimdi bu durum daha da açtı insanlar arasını. İnsanlar cenazeye, hasta ziyaretine gitmek istemiyor, virüs bahane oldu onlar için" (G5).

"İnsanlar arasında tokalaşmayı, kucaklaşmayı olumsuz yönde etkiledi. İnsanlar birbirlerinden korkar hale geldi. Şüpheyle birbirine bakmaya başladı. Ben de mi var onda mı var diye korkuyoruz. Birbirine gidip gelme olayı kalktı. En yakınımız ölüyor, korkudan cenazeye gidemiyoruz. En yakınımızın düğünü oluyor gidemiyoruz. Onlar da küsüyor" (G6).

"İnsanlar birbirine yaklaşmıyor. Kalıcı olacak bu. İnsanlar birbirine yaklaşmayacak. Çocuklarda özellikle. Çocuklar buna alışarak yetişiyor. Dışarı çıkınca hiçbir çocuğa yaklaşmıyor benim kızlarım ve ben bunun kalıcı olacağını düşünüyorum" (G7).

"Eski düzen çok samimiydi. Yeni düzen artık izole bir yaşamı gerektiriyor. Dokunursan, ölürsün moduna girdik. Resmiyet daha fazla artt1. Yeni normal düzen, yaklaşma, seviyeli dur, dokunma, uzaklaş demek. Kültürel olarak çok fazla mahrem nedir bilmeyiz. Herkesi hayatımıza dâhil ederiz. Çok samimiydik. Sosyal mesafe aslında herkesin hayatında olması gereken bir şeydi. Benim yakınıma gelme, yaklaşma bana demek. Yeni sosyal düzen bunu getirdi aslında" (G8).

"Toplum olarak çok sıcakkanlıyız. Sevsen de sevmesen de öpüşüyoruz, sarılıyoruz. En güzeli, sevmediğin insana da sarılmak zorunda kalıyordun, bu olmuyor en azından. Benim en çok zoruma giden, bayramda en sevdiklerimize sarılamadık. Alınanlar oluyor, ama farkında değiller ben uzak durarak, mesafeyi koruyarak seni koruyorum aslında. Sana verdiğim değerin göstergesi” (G9).

"Gerçek ilişkileri etkilemedi ama çok sevdiğim bir insana sarılmak için yönelsem, o da geri dursa ben de alınırım. Bizim kültürel yapımızda sarılmayı, dokunmayı seviyoruz, dokunsalız, dokunarak sarılarak sevgimizi belli ediyoruz. Bunlar olmayınca kısitlamalardan dolayı ilk başlarda insanlarda bir alınma falan oldu" (G12).

Virüsten korunmanın en etkili önlemlerinden birisi evde kalma süreci yani sosyal izolasyondur. Sosyal izolasyon ise, toplumsal ilişkileri etkilemektedir. İnsanların en önemli özelliği, sosyal olmalarıdır. Sosyal ilişkiler ağı, insanların yaşamlarını sürdürmelerinde hayati 
bir öneme sahiptir. Kültürel olarak sıcak ve samimi toplumsal ilişkilerin mevcut olduğu bir toplumda, sosyal izolasyon ilişkileri olumsuz yönde etkilemiş ve insanları birbirinden uzaklaştırmıştır. Aynı ortamda bir arada olmak, bir arada vakit geçirmek, iyi ve kötü günlerde beraber olmak gibi toplumsal ilişkiler yerini; aynı ortamda bulunmama, beraber vakit geçirmeme, iyi ve kötü günlerde birlikte olmamaya bırakmıştır. Bu durum ise, insanların birbirlerinden uzaklaşmalarına neden olarak, insanın sosyal olma özelliğini olumsuz yönde etkilemiştir. Toplumsal etkilerinin yanı sıra aile ilişkileri üzerinde de etkileri bulunmaktadır. Aile ilişkileri üzerindeki etkileri ise, şu şekildedir:

"Biz çok evde kalmadık, çalışıyorduk. Ama evde kalan insanlar için, uzun süre evde kalmanın gerginliği, huzursuzluğu aileye yansıyor. İnsanların sınır ve sabırları kalmadığ için ister istemez bu çocuğunuza ve eşinize yansıyor. Huzursuzluk arttı. İnsanların stresleri, sıkıntıları birkaç kat arttı Belli bir süreden sonra sabrınız kalmıyor. İnsanların ekonomik durumları çöküşe girdi. Ekonomik durumun yansıyacağı ilk yer ailedir" (G3).

"Eğer ebeveynler çalışıyorsa bu süreçte çok güzel vakit geçirdiler. Ekmeği bile evde kendimiz yaptık. Hem eğlendik hem de çocuklarla çok güzel vakit geçirdik. Kaliteli zaman için çok güzel bir vakitti. Ama bu süreci kaliteli bir şekilde geçiremeyenler de var. Çalışma süresi, aile üyelerine vakit ayıramama problemini ortaya çıkarmıştı. Beraber zaman geçirme süreleri arttı. Bu süreçte tartışanlar da oldu ama ben bu durumun daha temelden kaynaklı sorunlara bağlıyorum." (G1).

"Ben bir buçuk ay evde kaldım. Çok mutluydum inanın. Evde eşinden huzur bulmayan adam kendini dışarı atar. Evde huzur oldu mu dişarıyı hiç aramıyorsun. Evde kalmaya doyamadım. Ne sıkıldım ne de bunaldım. Bu yaşıma kadar evde ailemle düzgün kahvaltı yapmışlı̆̆ım yoktu. Onlarla beraber vakit geçirmenin tadına doyamadım. İnsanlar arasında sarılma kalmadı." (G5).

"Benim için ev en sevmediğim yer oldu. Sürekli kavga ettim eşimle. Bunaldım evde ben. Bütün hayatım boyunca hep çalışmış insanım, özel dersler falan, eve girmezdim. Bir anda eve kapanınca çok bunaldım. Özellikle küçük kızım yüksek sesle konuştuğunda cinnet geçirecek gibi oluyordum" (G7).

"İş yerimiz kapandı bu süreçte, evdeydik hep. O dönemde kayınpederim evdeydi, o yüzden çok zordu. Yaşlı kendisi, evde tutamıyoruz, köyünü özlüyor, evde sıkılıyor. Dışarı çıksa yasak, virüs bulaşabilir" (G9).

"Çocuklarımla çok güzel vakit geçirdim. Onlar adına çok iyi oldu. Onun dışında çok sıkıntılıydı. Kayınvalidem de bizdeydi. Kocam be sürekli evdeydik. Çok kavga ettik. Her şey gözümüzde büyüdü. Gözünün üstünde neden kaşın var moduna girdik artık. Zaten eşimle çok anlaşamıyordum önceden de" (G10).

"Çocuklar için gerçekten çok iyi oldu. Anne baba evde ve hep onlarla ilgilenme fırsatımız oldu. Dönelim bana, işe gitme fırsatımız olmadığımız işe hava almayan, eş ve ev işleri sana bakıyor, arada gelen kayınvalide ile sıkılma oranımızı taçlandırdım resmen. Mutfaktan çıkmadık. O da evden çıkamadığı için küçük gerginlikleri, çatışmalar olmadı değil, oldu tabi. Bir süre sonra sakinleştik. " (G13). 
Salgınla mücadele etmenin dünya genelinde en temel yolunun yakın ilişkilerin azaltılması yani sosyal izolasyon olması bazı olumsuzlukları da beraberinde getirmektedir. Diğer bir deyişle, virüsün insanlara bulaşma riskinin en aza indirilmesi için bireylerin "evde kalmaları" gerekmektedir. Bireylerin evde kalmaları ise aileleriyle ve eşleriyle hiç geçirmedikleri kadar fazla zaman geçirmeleri demektir. İşte bu noktada, virüs sadece insan sağlı̆̆ını olumsuz etkilemekle kalmayıp insanların aile hayatlarını ve evliliklerini de olumsuz yönde etkileyebilmektedir (Çukur vd., 2020, s. 30). Bu bağlamda, uzun süre birlikte vakit geçiren aile üyeleri arasındaki ilişkiler olumsuz yönde etkilenmiştir. Aile içi ilişkileri sorunlu olan bireylerin, bu süreçte sosyal hayattan uzak kalmanın vermiş olduğu gerginlik, aile içi ilişkilere olumsuz yönde yansıması olmuş ve tartışmalar artmıştır. Söz konusu olumsuzluklar karşısında, bu sürecin olumlu yönleri de olmuştur. Diğer bir ifadeyle, sürekli çalışan, evde vakit geçiremeyen, aile üyeleri olarak birbirlerine vakit ayıramayan bireyler için bu sürecin olumlu yansımaları olmuştur. Birbirlerine daha çok vakit ayırmış, beraber daha fazla vakit geçirmiş, çocuklarla kaliteli aktiviteler gerçekleştirilmiştir. Bu durumun doğal bir sonucu olarak aile üyelerine, özellikle çalışan ebeveynlerin çocuklarına yansıması olumlu yönde olmuş, aile ilişkileri kuvvetlenmiştir. $\mathrm{Bu}$ durumun tam tersini yaşayan ailelerin de mevcut olduğu görülmektedir.

\subsection{Koronavirüs Salgını ve Eşitsizlikleri}

Afetler, toplumsal sınıf/tabaka ayırmaksınız herkesi eşit biçimde vurur. Fakat afet yönetiminin önemli iki boyutu afetlere hazırlkklı olmak ve afetin etkilerini azaltmaktır ve bu aşamalarda toplumsal eşitsizlikler gün yüzüne çıkabilir. Toplumsal eşitsizlikler ise en fazla dezavantajlı gruplar aleyhine ortaya çıkar. Evsizler, yoksullar, engelliler, yaşlılar, çocuklar, kadınlar, göçmenler diğer nüfus kesimlerine göre salgın öncesinde zaten var olan kırılgan pozisyonlarından dolayı salgın sırasında ve sonrasında en olumsuz etkilenen grupları teşkil ederler (Akbaş, 2020, s. 5). Özellikle dezavantajlı gruplar söz konusu salgında daha çok etkilenmekte ve daha çok kayıplar yaşamaktadır. Söz konusu bu süreçte kazanmanın ötesinde, etkilenme dereceleri farklılaşmaktadır. Başka bir ifadeyle salgının toplumsal boyutlarına bakıldığı zaman, bireylerin ya da grupların bu süreci deneyimlemelerinde farklılıklar mevcuttur. Aynı durumla karşılaşan bireylerin farklı derecelerde hayatlarını etkilemekte ve eşitsizlik meydana gelmektedir. Söz konusu eşitsizlik genellikle eğitim, ekonomik yaşam ve sağlık gibi alanlarda kendini göstermiştir.

\subsubsection{Eğitimdeki Eşitsizlikler}

Eğitim, kültürün kuşaktan kuşağa aktarılmasında çok önemli rol oynar. Okul ise, birbirinden çok farklı ailelerden gelen, birbirinden çok farklı kişiliklere sahip olan çocuklara o toplumun temel değer ve önceliklerini öğreten kurumdur (Zencirkıran, 2017, s. 101). Toplumsallaşma sürecinin olmazsa olmazı, eğitim ve eğitimin yürütüldüğü kurum olan okuldur. Salgınla birlikte vaka sayılarının azaltılmasına yönelik atılan adımlardan birisini ise, eğitimin evde gerçekleştirilmesi oluşturmaktadır. Okul ortamından uzak bir şekilde gerçekleştirilen eğitimin, bireyler üzerinde etkileri bulunmaktadır. Söz konusu olan etkiler ise, şu şekildedir:

"Bir öğretmen olarak konuşuyorum. Kisıtlı oldu her şey. Zaman kısıtlı, koşullar kısıtll. Bir şeyi örgün öğretimde çok yönlü ve uygulamalı öğretecekken, online eğitimde daha azını öğretmiş oluyorsun. Yaparak yaşayarak öğrenmek her zaman daha kalıcı olur. Özellikle 8. Sınıf ya da 12. Sınıf öğrencilerini, kaderlerinin dönüm noktası olan bu süreçte çok olumsuz etkiledi. Sadece bu süreçte dijital eğitimde çocuklarda özdenetim sağlanmış oldu. Kendi sorumluluğunu alma özelliği kazandı. İlçede öğretmen arkadaşım var. Benim canlı dersime 32 kişi katılırken; arkadaşımın canlı dersine 2 kişi katılıyordu. Çünkü çoğu öğrencisi köyde yaşıyor.” (G1) 
"Eğitimi sıfırladı. Eba dersinden uzaktan ders versek de özellikle sıfırlandı. Fen lisesi öğrencilerim tamam, onlar bir şekilde bir aşamaya geldiler, özdenetimlerini sağlayabiliyor ve çalışıyorlardı. Bundan bir yıl önce çocukların ellerinden telefonları alıyorduk e uzaklaştırıyorduk. Şimdi kendi elimizle telefonu ellerine veriyoruz. Aileler yetersiz kaldı" (G7).

"Eğitim biraz askıda kaldı. Tamam, teknoloji çağının güzel nimetlerinden yararlanıldı. Bence öğrenciler bundan verim alamadılar. Öğretmen-öğrenci ilişkisi yüz yüze olmalı. Dijitalde öğrenci dinlemiyor ki. Sinıf ortamında bile dikkatlerini toplamaları zorken, uzaktan eğitim de işler iyice zorlaştı. Dijital değil, kalemin defterin olacak, not alacaksın. Öğrenme çok sınırlıydı havada kaldı. Herkes şehirde yaşamıyor. Herksin interneti, tableti yok. Köyde yaşayan insanların android telefonu var $\mathrm{m} ı$ yok mu? Onu geçtim telefon çekmeyen yerler var. O köyler adam yollamak, eğitimlerini sürdürmek ne kadar zor olabilir" (G8).

"Ben buradayım, çocuğum evde derse girdi mi bilmiyorum. Kontrol edemiyorum. Okulda öğretmenlerle rahattı. E ben çalışıyorum gündü, ne kadar ulaşabilirim onlara. Ne kadar çocuk eğitim alacak ki” (G10).

"Çok değiştirdi. Genelde dezavantajlı oldu çocuklar açısından. Eğitim yüz yüze olan bir süreç. Eğitim, öğrenci, öğretmen ilişkisi isteyen, anlayıp anlamadıklarını ögrencilerin gözlerinden anlayan bir yapı gerektirir. Evde üç dakika seni dinlese bile dördüncü dakika odanın duvarına, avizesine dikkati dağılıyor. Dinlemiyor seni. Aileyle ilgili sesler çocuğun dikkatini dağıtıyor. Birçok aile, çocuğa sessiz bir ortam sağlamadı. Benim dersimde çocuk canlı derste, arkada annesi bulaşık yıkıyor hem de çocuğa laf sayıyor. Akşam baban gelsin yaptıklarını söyleyeceğim, diyor. Çocuk bu ortamda nasıl çalışsın ya da nasıl öğretmenini dinlesin. Güzel yanı ne oldu, çocukların özdenetimini arttırdı. Okulda bütün denetim bizdeydi. Bu süreçte çocukların da artık bir şeyler öğrenmeye karar vermeleri gerektiğini, aksi takdirde yol alamayacaklarını fark ettiler. $\mathrm{Bu}$ gerçekten özdenetim açısından çok iyi oldu." (G13).

"Önceden çocukların başında birisinin durma zorunluluğunu hissediyorduk. Sürekli birinin dersi vermesi gerekiyordu. İnsanlar şimdi kendi kendine öğrenme yoluna gitmeye başladılar. Kendi kendine araştırmak zorunda kalıyor, sistemi öğrenmek zorunda kalıyor. Aile bir yere kadar yetişiyor, bir yerden sonra çocuk kendisi çabalamak zorunda kalıyor.” (G18).

Pandemi ile çizilen tablo, genelde tüm eğitim sisteminde özelde ise yükseköğretim sisteminde dijital dönüşümün önem ve gerekliliğini ortaya koymaktadır. Bununla beraber dijital dönüşüm salt teknoloji yatırımı değil, dijital teknolojilerle desteklenen süreçlerin geliştirilmesi şeklinde yorumlanmalıdır. Bu düşüncelere ek olarak dönüşümün merkezinde kurumlar değil, öğrenenlerin ihtiyaçları olmalı; mevcut gereksinimlerin yanı sıra eğitim kurumlarını geleceğe taşıyacak vizyon ortaya konmalıdır (Bozkurt, 2020a, s. 124). Virüsün etkilediği ve dönüştürdügü alanların başında eğitim gelmektedir. Virüsün yayılmasını engellemek için alınan önlemlerin birisi de yüz yüze eğitim yerine online eğitimin gerçekleşmesidir. Gelişmiş teknolojiden yararlanarak gerçekleştirilen eğitim, esasında var olan teknik ve yöntemin etkili bir şekilde kullanılmasına dayanmaktadır. En önemli yanı ise, internetin, telefonun ve tabletin olduğu her yerde, belirli bir mekana bağlı kalmaksızın eğitimin gerçekleşebileceğidir. Bu 
sürecin diğer bir katkısı ise, öğrencilerin yine aynı şekilde belirli bir mekâna bağlı kalmaksızın, öğretmenin denetiminden uzak, kendi öz denetimlerini sağlayabilme yetisi kazanmaları olmaktadır. Okulda, sınıfta ve öğretmenin denetimi altında gerçekleştirilen eğitim, online eğitimle birlikte öğrencinin eğitimi hakkında kendi sorumluluğunu alması, önemli bir kazanım olarak karşımıza çıkmaktadır. Söz konusu kazanımların dışında bu sürece bağlı olarak ortaya çıan belirli eşitsizlikleri de gündeme getirmiştir. Online eğitimle birlikte her evde teknolojik aletlerin şehir köy fark etmeksizin bulunmaması, gerçekleştirilen eğitimi sekteye uğratmıştır. Eğitimi alan öğrenci sayısına oranla teknolojik aletlerin bulunmaması ve ders saatlerinin çakışması, eğitimi alan öğrenciler adına dezavantajlı bir durum olmuştur. Ayrıca ev ortamında gerçekleştirilen eğitim, diğer bir dezavantajı durum olarak karşımıza çıkmaktadır. Ailelerin öğrencilere eğitimi alabilecekleri belirli bir ortam sağlayamamaları, öğrencilerin aldığı eğitimi olumsuz yönde etkilemiştir. Eğitimi alabilecekleri güzel bir ortam sağlanmış olsa bile belirli yaş grubunda bulunan öğrenciler üzerinde ebeveyn kontrolünün eksik olması, başka bir olumsuzluk olarak karşımıza çıkmaktadır. Başka bir ifadeyle çalışan ebeveynlerin, çocuklarının aldıkları eğitimi kontrol edememeleri, çalışmayan ebeveynlere göre dezavantajlı konumda olmalarına neden olmuştur. Dolayısıyla virüsle birlikte dezavantajlı konumda bulunan eğitim, kendi içerisinde farklı sorunları barındırarak eşitsizliklerin kaynağını oluşturmaktadır.

\subsection{2. Çalışma Hayatındaki Eşitsizlikler}

Halk sağlığının yanında toplumsal yaşamı da derinden etkileyen Covid-19 salgını, salgın nedeniyle can kayıplarının yanı sıra devasa bir iş ve gelir kaybı da yaşanmaktadır. İnsan sağlığına değil üretimin her koşulda devam etmesine, çarkların dönmesine odaklı politikalar sadece işçilerin sağlığını değil, toplumun tamamının sağlığını tehdit eder bir noktaya gelmiştir (Çerkezoğlu, 2020, s. 471). Salgınla birlikte, işgücü piyasasındaki farklı sektörler çeşitli zorluklara neden olmuş, bu zorluklar da diğer sektörleri de olumsuz etkileyerek milyonlarca çalışan insanın bu süreçten olumsuz etkilenmesine sebep olmuştur (Serçemeli, 2020). Söz konusu etkiler ise, şu şekildedir:

"Her yönüyle olumsuz bir şekilde etkiledi. İşlerimiz azaldı. Hele ki küçük esnaflar bitti. Çoğunluğu kapattı, işi düştü. Borcu olanların iyice borcu arttı. Biz hizmet sektöründe olduğumuz için çalışmak zorundaydık. Covid hastanesinin tam karşısındayız. Doktoru geliyor, hemşiresi geliyor. Geliyorlar ama korkuyorduk. Acaba onlarda varsa bize bulaşırsa diye." (G6).

"İşin mahiyetine göre iş yaşamımız şekillendi. Virüsün ilk çıktı̆̆ 1 dönemlerde, bizim birimde olanlar haftada bir kere gidiyorduk dönüşümlü. Diğer birimlerde olanlar haftanın her günü gitmek zorundaydı. Hiç gelmeyen memurlar da vardı. Dediğim gibi, işin mahiyetine göre çalışma yaşamımız şekillendi bu süreçte. Evde çalışan, evde işini sürdüren insanlar var. Onlar daha avantajlı. Sen herkesin kullandığı otobüsü kullan işe git, risk altında ol. Diğeri evinde rahat rahat çalışsın. Sen vatandaşlarla iç içesin. Bu durum eşitsizdi. Polisler halkla iç içe, insanlarla sürekli temas halinde. Yine doktorlar birebir hastalarla temas halinde. Onlar bu süreçte daha çok risk altındalar ve çalışmak zorundalar" (G2).

"Ekonomimiz çok kötü etkilendi. Bu yüzden herkese evde kalın denilmiyor. Okullar açılmak zorunda kantinci, servisler iş yapmak zorunda. En basitinden okul kapatıldığında kaç sektör iş yapamaz hale geliyor. Birçok insan para kazanamıyor. Bunların hepsi zincirin halkası gibi birbirine bağlı. Devletin bütün ekonomiyi yüklenecek gücü olmadığı için, normal hayata devam ediyor gibi kurumlar açılıyor. Mecburiyetlerimizin doğurduğu sonuçlar.” (G1). 
“Küçük işletmelerin hepsi çöktü bu süreçte. Benim eniştemin avm’de bir dükkanı vardı. Bu süreçte Avm'ler kapandı, haliyle birkaç ay çalışamadı, para kazanamadı. Sonra avm'ler açıldı, çalışmaya başladı ama bu süreçte çalışanlarına para vermekten adam battı. En sonunda kapatmak zorunda kaldı dükkanı. Bu süreçte küçük insanları çok olumsuz yönde etkilerken, büyük insanların kazançlarına kazanç kattılar" (G16).

"Avmler falan kapandı ya aslında daha az israf olaya başladı. İnsanlar çılgınlar gibi alış veriş yapmadılar, tüketmediler. İhtiyaç dışı alımlar k1sıtland1. Sokağa çıkma yasağı olduğu anda insanlar gıdaya yöneldi, insanlar iktisat yapmayı ögrendi. Aslında mecburiyetler, insanları gelişime açtı. İşini kaybetti ama başka ne yapabilirim diye düşündü, başka potansiyellerinin farkına vardılar. Yeni iş kapıları araştırmaya başladılar. Değişiyoruz, dönüşüyoruz, dünya olarak değişiyoruz artık. Krizi, virüsü fırsata çevirmek lazım. Yeni iş kapılarına yönelmek gerekiyor. İnsanlar buna ayak uydurabilmeli. Zorunlu ama iyi bir şey oldu. Zor olacak tabi, ama insanları geliştirir bu" (G18).

"Biz burada covidli hastalarla aynı havayı soluyarak çalışalım, evde oturup maaşlarını alan çok insan oldu. Özellikle öğretmenler, ek ders ücretlerini bile aldılar. Bu da çok büyük bir eşitsizlik. Haberlerde çıtı coronalı hasta dişarıda limon satarken görüntülendi. E adam ne yapsın şimdi evine para girmiyorsa, ekmeği kim getirecek. Mecbur çalışmaya. Ama bir taraftan da hastalığı bulaştırıyor. O kadar sıkıntılı bir süreç ki. Adaletsizlik çok fazla var gerçekten. Ama bir taraftan akış durmalı ki, insanlar evlerinde oturmalı ki virüs bitsin. Neresinden tutarsan elini yakıyor insanın" (G20).

Söz konusu süreçte ekonomik yaşamda karşılaşılan eşitsizlikler kaçınılmaz bir hale gelmiştir. Söz konusu eşitsizliklerin iki boyut üzerinden şekillendiği görülmektedir. Bunlardan ilkini, salgın döneminde getirilen kısıtlamalarda kapatılan iş yerleri oluşturmaktadır. Virüsten korunmak ve insan akışını durdurmak amacıyla çoğu iş yeri kapatılmıştır. İş yerlerinin kapatılması çalışma hayatının sekteye uğratmış ve üretimin sürekliliği üzerinde olumsuz yönde etki etmiştir. Bu durum hem işverenlerin hem de çalışanların birçoğunun işini kaybetmesi anlamına gelmektedir. İşini kaybeden insanların gündelik hayatta yaşadığı sorunların temelini bu süreçte işini kaybetmeleri ve ekonomik olarak bir gelire sahip olamamaları oluşturmaktadır. $\mathrm{Bu}$ bağlamda, bir kamu kurumunda çalışıp maaşını alanlar karşısında işini kaybeden insanların yaşadığı olumsuz durum, eşitsizliğin önemli bir kaynağını oluşturduğu görülmektedir. Çalışma yaşamında meydana gelen kısıtlamalar, iş yerlerinin kapatılması, çalışanların işlerine son verilmesi, çalışma hayatında farklı meslekler arasındaki avantaj ve dezavantajlı durumlar gibi uygulamalar, Covid-19 salgınının ekonomi sahasında neden olduğu olumsuz sonuçlara işaret etmektedir.

Öte yandan, salgın sürecinde meydana gelen eşitsizliğin bir diğer boyutunu ise, virüse uzaklık ve yakınlık derecesinde çalışma faktörü oluşturmuştur. Pandemi sürecinde işini kaybeden insanların yaşadığ 1 eşitsizlik durumunun karşısında, risk altında çalışan insanların yaşadığı eşitsizlik durumu bulunmaktadır. Sağlık çalışanlarının, polislerin, gıda sektörü gibi hizmet sektöründe hizmet verenlerin, bazı kamu kuruluşlarında çalışanların birebir virüsle karşılaşma olasıllı̆ı yüksek olmasından dolayı büyük bir tehdit altında çalışmaktadırlar. Bir diğer taraftan bu süreçte homeoffice şeklinde çalışmaya devam edenler, esnek çalışma saatlerinin mevcut olduğu işlerde çalışanlar, virüsle karşılaşma olasılığı düşük olduğundan dolayı avantajlı konumda yer almaktadırlar. Dolayısıyla risk altında çalışan insanların riskten uzak çalışma ortamına sahip olan insanlar karşısında dezavantajlı konumda bulunmaları, ekonomik yaşamda karşılaşılan bir diğer eşitsiz durum olarak karşımıza çıkmaktadır. 


\subsubsection{Sağlık Alanındaki Eşitsizlikler}

İnsan hayatının en önemli ve değerli yönünü oluşturan sağlığın korunması ve sürdürülmesi sosyolojik açıdan merkezi öneme sahiptir. Örneğin hangi semptomların hastalık belirtisi olup olmadığ 1 , bireylerin tedavi ve doktor tercihleri, tıbbi konulardan çok toplumun kültürü ve yapısıyla ilgilidir. Bunun dışında sağlık alanında oluşan gruplar ve bu grupların diğer grup ve toplumsal yapıyla ilişkisi, bir kurum olarak sağlık kurumunun işleyişi, diğer kurumlarla ilişkileri ve değişimleri sosyolojinin inceleme alanına girmektedir (Aytaç ve Kurtdaş, 2015, s. 232). Dolayısıyla, sağlık toplumsal bir konu olmasının yanı sıra toplumda gerçekleşen değişimlerden de etkilenen bir yapıya sahiptir. Nitekim salgın döneminde etkilenenlerin başında sağlık kurumu ve sağlık çalışanları olmuştur. Salgın döneminde ise, sağlık hizmetleri, önemini korurken; sağlık hizmetleri şu şekilde gerçekleştirilmiştir:

"Sağlık alanında çok güzel çalışmalar oldu. Eşitsizlik çok olduğunu düşünmüyorum. Süreç çok iyi ilerledi. Korana kendi başına olan bir hastalık değil. Bireysel bir hastalık değil, toplumsal bir hastalık. Her birey çok değerli ülke vatandaşlarının. Yaşlılarımız bile çok değerli, o yüzden 65 yaş üstünün sokağa çıkmaması sıkça gündeme geldi. Onları korumak için" (G1).

"Elimizde bir güç varsa bunu millet olarak çok iyi paylaşıoruz. Verebileceğimiz şeyleri veriyoruz. Sağlık çalışanları çok özveriyle çalıştı. İstifa edebilirler. Hastalık alan oldu. Sağlık sisteminin iyi olduğunu düşünüyorum. Sadece bazı şeyler gözden kaçıyor gibi geliyor bana" (G11).

"Korkumuzdan hastaneye gidemiyoruz. Gittin mi seni özel hastaneye yönlendiriyor. Pandemi sürecinde normal hastane bakmiyor sana. Geçenlerde dişimle ilgili bir işlem yaptıracağım, normal hastaneler kapattı o servisi. Özel dişçilere mecburen gidiyorsun. E paras1 olmayan ne yapsin" (G5).

"Sağlık çalışanları bu dönemde yapılması gerekenlerinin kat kat fazlasını yaptılar. Ailelerinden uzaklaşıp hizmet vermeye başladılar. Sağlık Alanında eşitsizlik olduğunu düşünmüyorum. Sadece şu konuda sıkıntı yaşandı, herkes corona değil. Kalp hastası olanlar var, şekeri olanlar vardı. Bunlar biraz ötelendi. Daha doğrusu covid dışındakiler önemli değildi onlar için. Bu konuda biraz adaletsizlik oldu. Ayakta hasta gibi gördüler. Onlar da çok ciddi rahatsızlıklardı, ama ötelendi gibi geliyor bana. Kanser ne demek, kemoterapi alamadilar" (G8).

Salgın sürecinde en fazla etkilenen alanlardan birisi sağlık alanı olmuştur. Olumlu gelişmelerin yanı sıra eşitsizliklerin de mevcut olduğu görülmektedir. Pandemi sürecinde genç yaşlı fark etmeksizin herkes, en üst düzeyde koruma ve tedavi kapsamına dâhil olmuştur. Tedaviden faydalanma konusunda farklılıklar söz konusu olup, salgın sürecinde sağlık alandaki eşitsizlikler belirgin bir biçimde ön plana çıkmıştır. Hizmet konusunda söz konusu olan eşitsizlik, Covid-19 dışındaki hastalıklarda karşılaşılmaktadır. Salgın sürecinde Covid-19 dışındaki hastalıklar ikinci öncelikli sıraya geçerken, söz konusu hastalıklar ve hastaların tedavisi Covid-19 karşısında önemini kaybetmiştir. Dolayısıyla bu süreçte sağlık alanında karşılan eşitsizliklerin birini, covid-19 dışındaki hastalıklarda görülmektedir. Sözü edilen eşitsizliklerin bir diğerini ise, sağlık çalışanlarının karşılaştıkları dezavantajlı durumlarda görülmektedir. Sağlık çalışanlarının karşılaştıkları dezavantajlı durumlar aşağıdaki gibi ifade edilmiştir: 
"Hastaneden tanıdıklarım var. Çalışanlar açısından eşitsizlik var. Doktorların Covid mesaisi vardı ama hemşirelerin, hasta bakıcıların Covid mesaisi yoktu. Covidle birebir temas sadece doktorlar yaşamıyor. Orada hasta bakıcısı var, temizlikçisi var, eczane var. Bu yükün altına giren herkes var. Hafta da bir gün nöbeti olan doktora tavan maaş veriyorsunuz, her gün Covidli hastanın altını temizleyen hasta bakıcıya maaş vermiyorsunuz. Biz bir sürü hastayla yakın temas halindeyiz eczacı olarak. Ama biz yoktuk onlar için. Covid reçetesini alan bize geliyor. Temas oluyor. Herkesin çocuğu var" (G3).

"Bu süreçte en fazla sorun sağlık alanında oldu. En fazla mağdur olanlar sağlık çalışanları. Benim korkum sağlık çalışanlarının işi bırakması, ya da bırakın ölsün demeleri. Çünkü onlar içeride uzun saatler boyunca maskeli çalışıyor, dışarıda adam maske takmadığı için hasta oluyor ve herkesi tehlikeye sokuyor" (G7).

"Sağlık çalışanları çok özverili çalıştılar. Onlar kendilerini de karşısındaki insanı da nasıl koruması gerektiğini biliyorlar. Onlar dışardaki insanlardan korkuyorlar. Ben de virüsü taşıyıp da belirtisi olmayan insanlar korkutuyor. Asıl onlar yayıyor zaten. Bende bir şey yok nasılsa diye sosyal hayatta gezip dolaşıyorlar. Gezip dolaştıkça virüsü yayıyorlar. Sağlık çalışanları o kadar saat maskeli çalışıyor, ne kadar zor bir şey, bizim insanımız bir şey yok diye gezip dolaşıyor" (G9).

"Hastanede temizlik personeli \%100 riskin içinde. Fakat biz hastanenin verdiği, bakanlığın verdiği bütün ödeneklerin dışındayız. Covid farkını herkes alıyor, hastanenin temizlik ve güvenlik personeli almıyor. Hastanenin içindeki eczanedekiler Covid farkı alıyor, ama biz almıyoruz. Dişte çalışan farklı şirket elemanları vardı. Onlar tamamen haksızlığa uğradı şirket tarafından işten çıkarıldılar" (G14).

"Mesela ben de risk altındayım burada, hemşireler de hasta bakıcılar da, temizlikçilerde. Bize ilk başta tavandan döner sermaye vermeye başladılar, ama onlara vermediler. Ama gerçekte hastayla hepimiz haşir neşiriz. Sadece yoğun bakımda çalışanlara verildi. Çok dert değil, biz görevimizi yaptık ama adaletsizlik yani. Herkes burada risk altında, yakın temas halinde." (G15).

"Biz büyük bir riskin altında çalıştık. Evinde çalışanlar vardı ya da evinde oturarak maaşını alanlar vardı. Bu çok büyük bir eşitsizlik bence. En belirgini öğretmenlerdi. Öğretmenlerin ek derslerini bile verdiler.. O kadar ihtiyacı varken, dükkânını kapatan varken. Neyle geçindiler ben bilmiyorum. O öğretmenlerin aldığı para çok tepki aldı. Bize vermediler ek ödeme. Herkes evinde oturdu maaşını aldı, kendini korudu. Biz büyük bir risk alarak hastanedeydik" (G19).

Tehdit karşısında herkesin biyolojik anlamda eşit olduğu iddia edilebilirse de gerek salgından korunma uygulamaları gerekse teşhis ve tedavi süreçlerinde eşitsizliklerle örülü bir gerçekliği deneyimliyoruz. Neredeyse sayısız sağlamanın yapıldığı ve artık olgusal bir gerçeklik kazanmış olan bu durum, özellikle salgın gibi büyük kriz durumlarında toplumun alt tabakalarındaki kesimler için çok daha yıkıcı sonuçlar üretir. Bugün dünya işgücünün dörtte üçünü oluşturan yaklaşık üç milyar işçinin salgından etkilendiği dikkate alındığında, krizin orta ve uzun vadeli etkilerini sınıfsal bir ayrım üzerinden tespit etmek mümkün olabilir (Yaman, 2020, s. 53). Sözü edilen tespit sağlık çalışanlarını da kapsamaktadır. Sağlık çalışanları tartışmasız bir şekilde salgın sürecinden en fazla etkilenen ve bu süreçte en fazla aktif görev 
alanında bulunan grup olarak karşımıza çıkmaktadır. Virüsle birebir temas halinde görev yapmaları, sağlık çalışanlarının özel bir konumda olmalarına neden olmaktadır. Özel bir konumda olmalarına rağmen, sağlık çalışanlarının da karşılaştığı eşitsiz durumlar mevcuttur. Diğer meslek dallarına göre daha fazla riskli alan içerisinde görev yapmaları karşılaştıkları eşitsizliğin temelini oluşturmaktadır. Ayrıca aynı risk alanı içerisinde görev yapmalarına rağmen, sağlık çalışanlarının da kendi aralarında mevcut olan eşitsiz konumları bulunmaktadır. Nitekim doktor, hemşire, hasta bakıcı, temizlik personeli, tıbbi sekreter, eczane çalışanları gibi hizmet verenler aynı risk alanı içerisinde yer almaktadırlar. Ortak risk alanı içerisinde bulunmalarına rağmen, çalışanlarının hepsi aynı ek ödenekten yararlanamamıştır. Dolayısıyla bu durum, sağlık çalışanlarının, kendi grupları içerisinde, belirli oranda eşitsizliğin mevcut olduğu görülmektedir.

\subsection{Toplumsal Cinsiyete Göre Koronavirüs Salgını Deneyimi}

COVID-19 salgını sağlik, ekonomi, eğitim ve sosyo-kültürel alanlar başta olmak üzere toplumun en temel kurumu olan aileyi de derinden etkilemektedir. Ailenin yapısı, işlevleri ve aile içindeki rollerin dönüşümü belirgin bir şekilde kendisini göstermektedir. Konuya Türkiye özelinde baktığımızda, ilk Covid-19 vakalarının görülmesinin ardından 16 Mart 2020 tarihinde okullara ara verilmesiyle ailelerin gündelik yaşam pratikleri bir anda değişmiştir (ZeybekoğluAkbaş ve Dursun, 2020, s. 80). Toplumsal cinsiyet perspektifinden bakıldığında, gündelik yaşam pratikleri değişen kadın ve erkekler, bu süreci farklı bir şekilde deneyimlemiştir. Bu anlamda Erzurum'da yaşayanların, salgın sürecinde gündelik yaşam pratikleri şu şekilde gerçekleşmiştir:

"Erkekleri daha çok etkiledi sanki. Kadınlar arkadaşları ile görüşemedi, günlerine gidemedi. Erkekler ise, maç beraber izleyemiyorlar. Kahvehane kültürü var burada. Erkekler kahveye gidemiyorlar. Esasında sosyal hayat kısıtlandığı için kadın da erkek de çok zorlandı bu noktada" (G1).

"Kadınlar daha çok ehemmiyet veriyor. Bunu kadınlar genel özelliğine bağlayabiliriz. Temizliği çok sever kadınlarımız. Onlar çok zorlanmadı bu süreçte" (G3).

"Kadınları çok olumsuz yönde etkiledi. İş yükleri arttı. Bütün ev halkı aynı yerdesin, yemek olayı arttı. Markete gidince her şeyi yıka yerleştir. Erkekler rahatladı. İş hayatına gidiyor, evde dinlenip yatıyor, sabah işe gidiyor. Sadece sosyal hayatları kısıtlandı. Kadınların ev yükü arttı. Kadınlar daha fazla dikkat ediyorlar. Erkeklerin abana bir şey olmaz tavırları daha fazla" (G8).

"Toplumda hali hazırda kadına biçilen roller var. Bu roller azalmadı ki arttı. Kadın evde, çocuklar daha fazla evde, eşler yine aynı şekilde. Kadının sorumlulukları daha çok arttı. Hele bu kadın çalışıyorsa, eve temizlikçi gelmedi, çocukların bakıcısı çağırılmadı. Bunların hepsi yine kadına kaldı. Virüs bulaşmasın diye. Kadınları özellikle yıpratan bir süreç" (G12).

"Kadınlar da daha çok eve kapandı, ama kadıların iş yükü inanılmaz arttı. Alış veriş yapmak istemiyorum, getirdiklerimi tek tek yıka yerleştirmekten dolayı. Çocuklar ben de, ev işi yemek her şey bende. Sabahtan akşam yatana kadar kimsenin isteği bitmiyor. Ayrıca canlı dersler oluyor, okulu da eve taşıdık. Ev içerisinde o kadar çok yüküm artt1 ki" (G13).

Salgın sürecinde kadınları ve erkekleri farklı boyutlarda etkilemiş̧ir. Erkeklerin sosyal alan faaliyetleri azalmıştır. Sosyal faaliyetleri azalan erkeklerin bu süreci daha çok ev içerisinde 
ailesiyle birlikte vakit geçirmiştir. Bunun dışında iş kaybına uğrayan bir erkek maddi ve psikolojik olarak olumsuz yönde etkilenmiştir. Dolayısıyla bu durumun aile bireylerine yansımaları olumsuz yönde gerçekleşmiştir. Kadınlar da ise, durum daha farklı bir boyutta ilerlemiştir. Kadınları genel olarak etkileyen durum, virüsü kendisinden ve ailesinde uzak tutmak için temizlik aktivitelerinin artışı ve sorumluluğu olmuştur. Virüsten korunmanın ilk şartı olan temizlik ve hijyen, kadınların daha fazla dikkat etmelerine, daha fazla enerji harcamalarına neden olmuştur. Ayrıca çalışan kadın perspektifinden bakıldığında, iş yüklerinin arttı̆̆ 1 görülmektedir.

Pandeminin getirdiği karantina, online çalışan kadınlar için çocuk bakımı, temizlik ve yemek konusunda dışarıdan hizmet alma imkânını ortadan kaldırmıştır. Bu da çalışan kadının yükünü büyük ölçüde artırmıştır. Nitekim sürekli yorgunluk ve bitkinlik hissediyorum diyen kadınların oranı erkeklerden daha fazladır. Bu kadınların erkeklere göre strese dayanıklılığ 1 kadar artan iş yükü ile de ilişkilidir. Özellikle özel sektörde online çalışan kadınlar arasında kamuda çalışanlara ve kendi işini yapanlara göre sürekli yorgunluk ve tükenmişlik hissi içinde olduklarım söyleyenlerin oram artmaktadır (Bozkurt, 2020b). Salgın sürecinde, temizlik, yemek, çocuk bakımı için yardımcı elemanlar, virüsün yayılma tehlikesi ve korkusuyla bu süreçte devre dışı bırakılmıştır. Dolayısıyla sözü edilen işler, yine kadının görevi olarak kalmış ve kadınlar bu iş yükünü sürdürmeye devam etmiştir. Ayrıca çalışan kadınların, salgın döneminde evde çalışmaya başlamaları, iş yüklerini ikiye katlamıştır. Evde gündelik yaşamda kadını bekleyen sorumluluklarının yanı sıra, ev içerisinde çalışma yaşamını da sürdürmeye devam etmiştir. Bunun dışında salgın nedeniyle çocukların eğitimi evde online olarak gerçekleştirilmiştir. Bu süreçte çocukların eğitiminin devamı ve kontrolü kadınların görev alanı içerisine dâhil olmuştur. Bu süreç, kadınların iş yüklerinin artmasına neden olmuştur.

\subsection{Kaygı, Korku ve Beklenti Sarmalında Koronavirüs Salgını}

Her ne kadar geçmişte büyük salgınlar tecrübe edilmiş olsa da bu deneyimlere rağmen Covid-19 salgınında küresel düzeyde bir panik ve çaresizlik durumu hâkimdir. Bu süreçteki belirsizlik ve beklenmedik ve alışı olmadığımız ölüm sayılarının insanlığı kısa ve uzun vadede derinden etkileyeceği kaçınılmaz görünmektedir (Taştan, 2020, s. 15). Bu anlamda Erzurum'da yaşayanların salgın deneyimi ve salgın karşısındaki kaygı, korku ve beklentileri şu şekilde gerçekleşmektedir:

"Beni en çok kaygılandıran şey sağlık. Bu virüsün bu dikkatsizlikle 2021'in sonuna kadar süreceği endişesi var bende. Vaka çok, kısıtlama yok, kısıtlamayı sürdürecek ekonomi de yok. Beni bu süreçte en fazla sağlik ve ekonomi endişelendiriyor" (G1).

"Beni en çok kaygılandıran şey ekonomi. Kurlar sürekli yükseliyor. Alım gücü gittikçe azaldı ve azalıyor" (G2).

"Çocuklarımın geleceğinden korkuyorum. Hastalığa yakalanma korkum yok. Yakınlarıma bulaştırma endişem daha fazla. Virüsün ne kadar süreceği belli olmadığı için maddi olarak neyin beklediğini bilmiyorum" (G3).

"Bu sürecin daha ne kadar daha devam edeceğini bilmiyor oluşumuz beni çok endişelendiriyor. E bunun ekonomik olarak çok daha ağır bir yükü var. Geleceğimizi öngöremiyoruz. Belirsizlik var. Ne tür zamlar bizi bekliyor bilmiyoruz. Bütün bu olumsuz koşulların ekonomiye nasıl yansıyacağını bilmiyoruz. Dolar, altın aldı başını gitti. Piyasa altüst oldu. Bu daha ne kadar sürecek" (G6).

"Ailem, sevdiklerim, ya onlara bir şey olursa. Gelecek kaygısı çok fazla var. Salgından önce hayal edebiliyordum, salgından sora hayal edemiyorum." (G8). 
"Hastalık gelmesin, etrafındaki sevdiklerine gelmesi, beni en çok kaygılandıran şey bu. Sen ne kadar dikkat edersen et, diğer insanlar dikkat etmeyince ben bu kadar neden emek verdim diyorsun. Ne getirip ne götüreceğini bilmediğim için korkutuyor" (G11).

"Görmediğin bir şeye savaş vermek yeterince ürkütücü. Görmüyorsun ve savaşmak zorundasın. Tedbiri bir an bile olsa elden bırakmamak zorundasin. Nas1 bir hayat bizi bekliyoruz, Ailemden birini kaybetme korkusu çok fazla. İleriyi görememek korkutuyor, ailenden birini kaybetme korkusu yaşıyorsun." (G12).

"Ya ölürsem ya da birinin ölümüne sebep olursam" (G14).

"Etrafımdaki yaşlı ve kronik hastalığı olanlara bulaştırma riski. Sağlıklı olan sevdiklerime de bulaştırmaktan çok korkuyorum" (G18).

"Normal hayata geçememek, insanların hep maskeyle dolaşacak oluşu. Bizim çocuklarımı belki iyi bir eğitim nasıl alacak. Normal bir hayata geçemezsek ne olacak" (G19).

Risk, daha çok bilindik, alışıldık davranış örüntülerinin dışında yer almaktadır. Gelecek, doğal olarak bilinmemektedir Dolayısıyla risk hesaplaması netlik kazanmaz. Risk ortamlarında, öngörülemeyen, belirlenemeyen sonuçlar her zaman güncelliğini korumaktadır (Giddens, 2010). $\mathrm{Bu}$ anlamda risk toplumunun en önemli özelliği, risklerin hesaplanamamazlığıdır. Hesaplanamayan tehditler, sürekli birikmekte herkesi etkileyen bir sorun olarak karşımıza çıkmaktadır (Beck, 2011). Modern riskler, teknolojinin ürettiği riskler olarak karşımıza çıkmaktadır. Fakat günümüzde ortaya çıkan covid-19 salgını, insanların varlığından beri, insanları sürekli olarak tehdit eden risklerin başında salgınların geldiğini hatırlatmıştır. Dolayısıyla her riskte olduğu gibi salgınlarda da kendi süreci içerisinde belirsizliği ve tahmin edilemezliğini barındırmaktadır. Virüsten korunmaya çalışsak da virüsün kendisinin ne olduğunun bilinmezliği insanları en çok kaygılandıran durumların başında gelmektedir. Bilinmezlik ve belirsizlik, başlı başına kaygı ve endişe uyandıran bir durumdur. Bu durumun virüsle beraber gündelik yaşamda her şeyi etkilemesi ile birleşince, kaygı ve endişe de o oranda artmaktadır. Virüs ne zaman bitecek, aşı ne zaman bulunacak, aşının yan etkileri ne olacak, hastalığın tedavisinin gelecekte insanların organlarını hangi yönde etkileyecek gibi sorular, insanların endişelerinin başında yer almaktadır. Ayrıca virüsün, kendilerine ve çevrelerine bulaşması ve en yakınlarını kaybetme korkusu da büyük oranda insanları etkilemektedir. Bunun dışında ekonomik yaşamda yer alan dezavantajlı durumlar ve gelecek kaygısı, gelecekte kendilerini nelerin beklediğinin bilinmezliği de diğer bir kaygı boyutunu oluşturmaktadır. Dolayısıyla salgın, belirsizlik barındıran risklerin başında gelmesinden dolayı, kaygı, endişe ve korkuyu içerisinde barındırarak insanları tehdit etmektedir.

\section{Sonuç}

Koronavirüs, küresel bir salgın olarak karşımıza çıkmaktadır. Sınırları hızlı bir şekilde aşıp, mekâna bağlı olmaksızın tüm dünyayı etkisi altına almıştır. Bu özelliği itibariyle geçmişin risk ve tehlikelerinden özellikle karşılaşılan salgınlardan ayrılmaktadır. Bu haliyle insanları tehdit etmektedir. Bu anlamda, covid-19 salgınını konu edinen bu çalışma ile şu sonuçlara ulaşılmıştır:

1. Virüs ilk ortaya çıtıktan beri, insanlar kendilerinden ve çevrelerinden nasıl uzak tutacakları konusunda bilgi edinmeye çalışmış ve kurallara, özellikle hijyen kurallarına daha çok dikkat etmişlerdir. Sağlık kurallarına ya da tedbirlere uymayanların, ya virüsü önemsemeyenlerden ya da kültürel olarak samimi ilişkilerin yoğunlukta olmasından kaynaklanmaktadır 
2. Bu süreci evde geçiren ailelere önemli etkileri bulunmaktadır. İlk öncelikle iyi ve kötü günlerde beraber olma ritüeli üzerinde olumsuz yönde etkisi bulunarak, insanların birbirlerinden uzaklaşmalarına neden olmuştur. Ayrıca, sorunlu olan ailelerde, sosyal hayattan uzak kalmanın vermiş olduğu gerginlik ile tartı̧̧malar meydana gelmiştir. Söz konusu bu olumsuz tablonun yanı sıra, birbirlerine vakit ayıramayan aile bireyleri, bu süreçte kaliteli vakit geçirmeleri, aile ilişkilerini kuvvetlenmiştir.

3. Virüsün etkilediği ve dönüştürdüğü alanların başında eğitim gelmektedir. Gelişmiş teknolojiden yararlanılarak gerçekleştirilen online eğitimler, belirli bir mekana bağlı kalmaksızın her yerde eğitimin sürdürülebilmesi açısından önemli bir farkındalık oluşturmuştur. Ayrıca, öğretmenin denetiminden uzak, kendi sorumluluklarını alabilen öğrenci profilleri gündeme gelmiştir. Bu süreçte eğitimi alan herkesin, teknolojik aletlere ve internete sahip olamaması, aynı evde birkaç öğrencinin ders saatlerinin çakışması, ailelerin çocuklara çalışma ortamı hazırlayamaması gibi dezavantajlı sonuçlar doğurmuştur.

4. Salgın döneminde alınan tedbirler kapsamında, birçok iş yeri çalışmalarını zorunlu olarak durdurmuştur. Dolayısıyla birçok işveren ve çalışan işsiz kalmıştır. Salgın sürecinde meydana gelen eşitsizliğin bir diğer boyutunu ise, virüse uzaklık ve yakınlık derecesinde çalışma faktörü oluşturmuş̧tur. Pandemi sürecinde işini kaybeden insanların yaşadığı eşitsizlik durumunun karşısında, risk altında çalışan insanların yaşadığı eşitsizlik durumu bulunmaktadır. Sağlık çalışanlarının, polislerin, gıda sektörü gibi hizmet sektöründe hizmet verenlerin, bazı kamu kuruluşlarında çalışanların birebir virüsle karşılaşma olasılığı yüksek olmasından dolayı büyük bir tehdit altında çalışmaktadırlar. Bir diğer taraftan bu süreçte homeoffice şeklinde çalışmaya devam edenler, esnek çalışma saatlerinin mevcut olduğu işlerde çalışanlar, virüsle karşılaşma olasılığı düşük olduğundan dolayı avantajlı konumda yer almaktadırlar.

5. Salgın sürecinde, sağlık hizmetleri ve sağlık çalışanlarına büyük görev düşmüş ve büyük bir özveriyle çalı̧̧ışlardır. Salgın sürecinde herkes, covid-19 kapsamında en üst düzeyde koruma ve tedavi kapsamına dâhil olmuştur. Bu duruma karşılık sağlık alanında yaşanan olumsuz durum ise, covid-19 dışındaki hastalıkların ikinci öncelikli sırada yer almış olmalarıdır. Ayrıca sağlık çalışanlarının da kendi aralarında eşitsiz bir durumla karşılaşmışlardır. Aynı risk alanı içerisinde çalışan sağlık personellerinin aynı ek ödenekten yararlanmamış olması, salgın sürecinde yaşanan dezavantajlı durum olarak karşımıza çıkmaktadır.

6. Salgın sürecinde, kadınların iş yükünü daha fazla arttırdığg sonucuna ulaşılmıştır. Salgın sürecinde, temizlik, yemek, çocuk bakımı için yardımcı elemanlar, virüsün yayılma tehlikesi ve korkusuyla bu süreçte devre dışı bırakılmıştır. Dolayısıyla sözü edilen işler, yine kadının görevi olarak kalmış ve kadınlar bu iş yükünü sürdürmeye devam etmiştir. Salgın nedeniyle çocukların eğitimi evde online olarak gerçekleştirilmiştir. Bu süreçte çocukların eğitiminin devamı ve kontrolü kadınların görev alanı içerisine dâhil olmuştur. Dolayısıyla salgın sürecinde kadınların görev alanı ve iş yükü artmıştır.

7. Salgın dönemleri, kendi süreci içerisinde belirsizlik ve tahmin edilemezlik barındırmaktadır. Bilinmezlik ve belirsizlik, başlı başına kaygı ve endişe uyandıran bir durumdur. Bu durumun virüsle beraber gündelik yaşamda her şeyi etkilemesi ile birleşince, kaygı ve endişe de o oranda artmaktadır. Bu anlamda Erzurum'da yaşayanların, virüsün çabuk bitmesi, en yakınlarını kaybetmeden normal yaşam pratiklerine geri dönme beklentisi içerisindedirler.

Sonuç olarak Covi-19 salgını, küresel bir salgın olması nedeniyle, insanları, toplumları, ülkeleri etkilemektedir. Sınırları hızlı bir şekilde aşması, geçmişte yaşanan risk ve tehlikelerden önemli ölçüde ayrılmaktadır. İlk ortaya çıktığı andan itibaren belirsizliği, olumsuz etkileri ve ortaya çıkardığg eşitsizlikler üzerinde düşünülmüştür. Başka bir ifadeyle dezavantajlı durumlar ortaya çıkarmış ve toplum üzerinde olumsuz yansımaları olmuştur. Bu olumsuz tablonun yanı sıra, değişimin kaynağı olarak önemli farkındalıkların da temelini oluşturmaktadır. 


\section{Kaynakça}

Acar, M. (2020). Korona sonrası dünya: ekonomik, sosyal ve akademik hayatta ne değişecek, ne değişmeyecek? . M. Şeker \& A. Özer \& C. Korkut (Ed.), Küresel salgının anatomisi insan ve toplumun geleceği içinde (ss. 279-299). Ankara: Türkiye Bilimler Akademisi Yay.

Akbaş, E. (2020). Covid-19'un toplumsal etkileri. Kovid-19'un psikolojik faktörler açısından değerlendirilmesi ve politika önerileri. İ. Demir (Ed.). Kovid-19 ve sonrası disiplinlerarası bir yaklaşım içinde (ss. 36-41). ULİSA.

Aytaç, Ö. \& Kurtdaş, M.Ç. (2015). Sağlık - hastalığın toplumsal kökenleri ve sağl1k sosyolojisi. Firat Üniversitesi Sosyal Bilimler Dergisi, 25(1), 231-250.

Beck, U. (2011). Risk toplumu/Başka bir modernliğe doğru. K. Özdoğan ve B. Doğan (Çev.), İstanbul: İthaki Yayınları.

Bozkurt, A. (2020a). Koronavirüs (Covid-19) pandemi süreci ve pandemi sonrası dünyada eğitime yönelik değerlendirmeler: Yeni normal ve yeni eğitim paradigması. Açıköğretim Uygulamaları ve Araştırmaları Dergisi, 6(3), 112-142.

Bozkurt, V. (2020b). Pandemi döneminde çalışma: ekonomik kaygılar, dijitalleşme ve verimlilik. D. Demirbaş, V. Bozkurt ve S. Yorğun (Ed.), Covid-19 pandemisinin ekonomik, toplumsal ve siyasal etkileri. içinde (ss. 115-136). İstanbul: İstanbul Üniversitesi Yay.

Çerkezoğlu, A. (2020). Covıd-19 ve çalışma yaşamına etkileri. Türk Tabipler Birliği.

Çukur, C.Ş., Koçak Özel, T., Bahçivan, M. S. R. ve Gök, S. E. vd. (2020). Kovid-19'un psikolojik faktörler açısından değerlendirilmesi ve politika önerileri. İ. Demir (Ed.). Kovid19 ve sonrası disiplinlerarası bir yaklaşım içinde (ss. 24-35). ULİSA.

Edoğmuş, N. (2020). Kovid-19 salgını anlam yıkımına mı yoksa yeni bir anlamlandırmaya mı yol açacak?. L. Sunar (Ed.), Covıd-19 salgınının sosyolojik analizi-1 içinde (62-69). Toplumsal Yapı Araştırmalar Programı.

Erdem, Z. (2020). İşgücü piyasası. D. Demirbaş \& V. Bozkurt \& S. Yorğun (Ed.), Covid-19 pandemisinin ekonomik, toplumsal ve siyasal etkileri içinde (ss. 137-152). İstanbul: İstanbul Üniversitesi Yay.

Giddens, A. (2010). Modernite ve bireysel kimlik: geç modern çağda benlik ve toplum. Ümit Tatlıcan (Çev), İstanbul: Say Yayınları.

Karakaş, M. (2020). COVID-19 salgınının çok boyutlu sosyolojisi ve yeni normal meselesi. İstanbul Üniversitesi Sosyoloji Dergisi, 40(1): 541-573.

Karaoğlu, Ö. (2020). Salgınların iktisat tarihi. D. Demirbaş \& V. Bozkurt \& S. Yorğun (Ed.), Covid-19 pandemisinin ekonomik, toplumsal ve siyasal etkileri içinde (ss. 1-25). İstanbul: İstanbul Üniversitesi Yay.

Kılıç, O. (2020). Tarihte küresel salgın hastalıklar ve toplum hayatına etkileri. M. Şeker \& A. Özer \& C. Korkut (Ed.), Küresel salgının anatomisi insan ve toplumun geleceği içinde (1355). Ankara: Türkiye Bilimler Akademisi.

Lika, I. (2020). The possible geopolitical implications of the covid-19 pandemic. SETA, 63, 117.

Neuman, W. L. (2012). Toplumsal araştırma yöntemleri: nitel ve nicel yaklaşımlar I-II. Sedef Özge (Çev). İstanbul: Yayınodası Yayınları.

Özlü, A. \& Öztaş, D. (2020). Yeni corona pandemisi (covid-19) ile mücadelede geçmişten ders çıkartmak. Ankara Medical Journal, 2, 468-481. 
Punch, K. F. (2011). Sosyal araştırmalara giriş: nicel ve nitel yaklaşımlar. Dursun Bayrak, H. Bader Arslan ve Zeynep Akyüz (Çev.). Ankara: Siyasal Kitabevi Yayınları.

Robson, C. (2015). Bilimsel araştırma yöntemleri gerçek dünya araştırması. Ş. Çınkır ve N. Demirkasımoğlu (Çev.). Ankara: Anı Yayınları.

Serçemeli, C. (2020). Covid-19 pandemi sürecine çalışma hayatı ve iş hukuku açısından kısa bir bakış. TURAN-SAM Uluslararası Bilimsel Hakemli Dergisi, 12(46), 395-405.

Şenol, C. \& Bilsel, A. (2020). Türkiye'de covid-19 (coronavirüs) pandemisinin durumu ve algoritmik hesaplamaya göre gelecekteki durum analizi. Journal of Socıal, Humanities and Administratıve Sciences, 6(25), 535-546.

Tansü, Y. E. (2020). Küresel salgin tehdidi ve güvenlik: tarihsel süreç. Yunus Emre Tansü (Ed.), Gaziantep: İksad.

Taştan, C. (2020). Kovid-19 salgını ve sonrası psikolojik ve sosyolojik değerlendirmeler. Ankara: Polis Akademisi Yayınları.

Tekin, H. H. (2006). Nitel araştırma yönteminin bir veri toplama tekniği olarak derinlemesine görüşme. İstanbul Üniversitesi Sosyoloji Dergisi, 3(13), 101-116.

Tiryaki, B. (2020). Kriz zamanında başkasını düşünmek. L. Sunar (Ed.). Covid-19 salgınının sosyolojik analizi içinde (ss. 69-73), Toplumsal Yapı Araştırmalar Programı.

Yaman, F. (2020). Evlerin Gölgesi de Salgından Korur mu? L. Sunar (Ed.). Covid-19 salginının sosyolojik analizi içinde (ss. 53-58), Toplumsal Yapı Araştırmalar Programı.

Zencirkıran, M. (2017). Sosyoloji, Bursa: Dora Yayınları.

Zeybekoğlu Akbaş, Ö. \& Dursun, C. (2020). Koronavirüs (covid-19) pandemisi sürecinde özel alanına kamusal alanı sığdıran çalışan anneler. Avrasya Sosyal ve Ekonomi Araştırmaları Dergisi, 7(5). 78-94.

\section{ETİK ve BIILIMSEL İLKELER SORUMLULUK BEYANI}

$\mathrm{Bu}$ çalışmanın tüm hazırlanma süreçlerinde etik kurallara ve bilimsel atıf gösterme ilkelerine riayet edildiğini yazar(lar) beyan eder. Aksi bir durumun tespiti halinde Afyon Kocatepe Üniversitesi Sosyal Bilimler Dergisi'nin hiçbir sorumluluğu olmayıp, tüm sorumluluk makale yazarlarına aittir. Yazarlar etik kurul izni gerektiren çalışmalarda, izinle ilgili bilgileri (kurul adı, tarih ve sayı no) yöntem bölümünde ve ayrıca burada belirtmişlerdir.

Kurul adı: Artvin Çoruh Üniversitesi Rektörlüğü

Tarih: 31.12.2020

No: E-18457941-050.01.04-14077 